\title{
Migrant population and perinatal health
}

\author{
Dolores Raimondi, M.D. ${ }^{a}$, Cecilia E. Rey, M.D. ${ }^{a}$, María Victoria Testa, M.D. ${ }^{a}$, \\ Evelyn D. Camoia, M.D. ${ }^{a}$, Agustina Torreguitar, M.D. ${ }^{a}$ and Javier Meritano, M.D. ${ }^{b}$
}

\begin{abstract}
Introduction. The number of foreign migrants tends to grow. The situation of people living away from their own country is complex and has an impact on the public health system. The objective of this article was to analyze the perinatal risk of migrant mothers and their newborn infants in comparison to native Argentine mothers and their newborn infants.

Methods. Cohort study that included 2000 mothers and their newborn infants (1000 migrants and 1000 natives) assisted at a public maternity hospital.

Results. Native mothers had a higher rate of low birth weight newborn infants $(9.9 \%$ versus $5.3 \% ; p<0.01)$, primiparity $(42 \%$ versus $37 \%$; $p=0.012)$, and adolescent pregnancy ( $6 \%$ versus $1.3 \% ; p<0.001)$. Migrant women had a higher rate of poorly controlled pregnancies $(21.7 \%$ versus $13.4 \%$; $p<0.01)$, positive serology for Chagas disease $(3.2 \%$ versus $0.4 \% ; p<0.01)$, and newborn infants requiring phototherapy $(20.5 \%$ versus $14.3 \%$; $p=0.04$ ).

Conclusion. In our study, Argentine mothers had a higher rate of low birth weight newborn infants, primiparity and adolescent pregnancies, while immigrant women had higher rate of positive serology for Chagas disease, poor antenatal controls and more newborn infants requiring phototherapy.

Key words: perinatal care, international migration, low birth weight newborn infant.
\end{abstract}

http:/ /dx.doi.org/10.5546/aap.2013.213

\section{INTRODUCTION}

Migration is currently one of the

a. Clinical Pediatrics Ward, Hospital General de Niños Pedro de Elizalde, Buenos Aires.

b. Neonatology Unit, Hospital MaternoInfantil Ramón Sardá (HMIRS), Buenos Aires.

E-mail address:

Dolores Raimondi, M.D.: loleraimondi@hotmail. com

Conflict of interest: None

Received: 9-9-12

Accepted: 1-12-13 given the fact that, in addition to the difficulties they have to deal with because of linguistic barriers, customs, and culture, ${ }^{4}$ they usually live in an unfavorable financial situation and in a potentially discriminatory and hostile environment. ${ }^{5}$

$\mathrm{Numerous}$ international investigations have demonstrated that migrant populations are vulnerable; and such vulnerability leads to complicated social and health difficulties that pose a strong challenge on health care services. In Italy it has been shown that the risk of preterm birth is significantly higher among migrants $(p=0.015){ }^{6}$ while in Spain the prevalence of adolescent pregnancies was 3-5 times higher among migrants compared to Spanish women. ${ }^{7}$ Migrant women in Europe had a clear disadvantage in all outcome measures assessed: $43 \%$ of higher low birth weight risk, $24 \%$ of preterm delivery, $50 \%$ of perinatal mortality, and $61 \%$ of congenital malformations. ${ }^{5}$

Taking into account the high percentage of international migrating population who are seen in the Argentine public health system ${ }^{3}$ and that there are no studies about this subject conducted in this country, we decided to do this study to assess if migrant women and their newborn infants have a higher perinatal risk than Argentine women and their newborn infants.

\section{POPULATION, MATERIALS AND METHODS}

A retrospective cohort study was performed to analyze the population seen at the Hospital Materno Infantil "Ramón Sardá" (HMIRS) during 2009, which included international migrating women and their newborn 
infants and, Argentine women and their newborn infants. Pregnant women who were not followedup at the HMIRS were excluded due to lack of data in their medical records; newborn infants who had major congenital malformations were also excluded from the study.

The sample size was estimated at 2000 subjects (1000 Argentine women and 1000 international migrant women) based on the incidence of low birth weight infants $(<2500 \mathrm{~g})$; the national estimate was accepted for native women $(7.2 \%)^{8}$ while the estimate accepted for international migrants was about $50 \%$ higher $(12 \%)$, considering a power of $80 \%$ and an alpha error of $5 \%$.

The HMIRS registry book of births of 2009 was used to consecutively select the cases, and for each one of them, the following newborn infant was assigned to the control group. Data were obteined from medical records of mothers and newborns.

Mother's nationality was the prediction outcome measure; the remaining outcome measures included were:

- In the newborn infant: birth weight, gestational age (the priorities for establishing the age was as follows: by date of the last menstrual period, early ultrasound scan and Capurro's method), Apgar score at 5 minutes, days of hospitalization, respiratory distress syndrome (RDS), and phototherapy due to hyperbilirubinemia. ${ }^{9}$

- In the mother: age, marital status, type of delivery, parity, arterial hypertension, positive serology for toxoplasmosis, Chagas disease, Venereal Disease Research Laboratory (VDRL), hepatitis B virus (HBV) and human immunodeficiency virus (HIV), gestational diabetes ${ }^{10}$ and hepatic cholestasis. ${ }^{11}$

\section{Ethical considerations}

Approval was requested and obtained from the Ethics Committee in Research of the HMIRS.
All the information was recorded separately from personal data in order to preserve participants' identity.

\section{Statistical analysis}

Data were described using means and standard deviation (median and interquartile range when the distribution was not adjusted to normality) and rates with their corresponding 95\% confidence intervals. For independent samples, Student's tests were used to compare means, and Mann-Whitney's tests, to compare medians. The 2 test was used to assess differences between proportions. Differences were considered significant if $p<0.05$. The relative risk and the corresponding $95 \%$ confidence interval were calculated. The Epi Info 2002 and Epidat 3.7 software were used for statistical analysis.

\section{RESULTS}

Data from 2000 mothers and their newborn infants (1000 natives and 1000 migrants) were analyzed. The studied migrant population included women from Bolivia (56\%), Paraguay $(28 \%)$, Peru (14\%), and other countries ( $2 \%)$.

No differences were found between infants born from native and migrant mothers in relation to birth weight, length of hospital stay and rate of patients with a weight $<1500 \mathrm{~g}$, Apgar score at 5 minutes $<5$ points, or presence of respiratory distress syndrome. There were 16 infants with major congenital malformations who were excluded ( 9 born to native mothers and 7 born to migrant mothers).

Among native mothers, newborn infants had a higher rate of a birth weight $<2500 \mathrm{~g}(9.9 \%$ versus $5.3 \% ; p<0.001)$, a gestational age $<37$ weeks (16.6 versus 9.6; $\mathrm{p}<0.01$ ), and a lower rate of phototherapy requirement ( $14.3 \%$ versus $20.5 \%$; $p=0.04$ ) (Tables 1 and 2).

In relation to mothers, no differences were seen between both groups in terms of hypertension, positive serology for toxoplasmosis, VDRL, HBV

TABLE 1. General characteristics of the population under study

\begin{tabular}{lcccc}
\hline & Total $(\mathbf{n}=\mathbf{2 0 0 0})$ & Native women $(\mathbf{n = 1 0 0 0})$ & Migrant women $(\mathbf{n}=\mathbf{1 0 0 0})$ & $\mathbf{p}$ \\
\hline Maternal age (years) & $25.2 \pm 6.5$ & $24.7 \pm 6.6$ & $25.8 \pm 6.3$ & 0.14 \\
Primiparous women & $766(38.3 \%)$ & $420(42 \%)$ & $372(37.2 \%)$ & 0.012 \\
Vaginal delivery (\%) & $1492(74.6 \%)$ & $760(76 \%)$ & $740(74 \%)$ & 0.32 \\
Gestational age (weeks) & $39.2 \pm 2,1$ & $38.5 \pm 2$ & $39.2 \pm 2.2$ & 0.02 \\
Weight (grams)* & $3304 \pm 589$ & $3222 \pm 590$ & $3387 \pm 560$ & 0.09 \\
\hline
\end{tabular}

*Mean \pm SD 
or HIV, gestational diabetes or hepatic cholestasis. Migrant mothers had a significant lower rate of adolescent pregnancies (maternal age younger than 17 years old) $(1.3 \%$ versus $6 \% ; p<0.01)$ and a lower rate of primiparity $(37.2 \%$ vs. $42 \%, p=0.012)$ (Table 1). As far as the marital status, there was a higher rate of stable relationships among migrant women $(50.6 \%$ vs. $43.4 \%$; $p<0.01)$, while the rate of single mothers (no stable partner) among Argentine women was higher $(46.8 \%$ versus $38.6 \% ; p=0.03$ ).

In turn, migrant mothers had a higher rate of poorly controlled pregnancies $(21.7 \%$ vs. $13.4 \%$; $p<0.01)$ and positive serology for Chagas disease $(3.2 \%$ vs. $0.4 \% ; p<0.01)$ (Table 3$)$.

\section{DISCUSSION}

The number of international migrants has grown from an estimated 75 million people in 1960 to 191 million in 2005. ${ }^{12}$ Historically, migrating women have been a major component of international migration. International migration estimates by gender indicate that there is a high rate of women and female children in the overall volume of migrants over time: in 1960, women accounted for $47 \%$ of international migrants, reaching $48 \%$ in 1990 and almost $49.6 \%$ in 2005 .

The determinants of the mothers' biological status are related to their nutritional status, age and reproductive life, the presence of certain infections, and habits, such as smoking or alcohol consumption. Emotional status determinants are highly related to situations of inequality that result in psychosocial stress: financial inequality, gender inequality and, in multiethnic societies, origin inequality.

Migration flows are a current problem for the services provided at the HMIRS, therefore, we planned to study how the fact of being a migrant affects perinatal health. Several publications show unfavorable results for migrants when compared to the native population. Most investigations up to date have not been conducted in Latin American environments.

The results of this study are different in several of the studied conditions.

No significant differences were found in the following outcome measures: maternal age, mode of delivery, average weight, length of hospital stay, Apgar score at 5 minutes,

TABLE 2. Neonatal outcomes

\begin{tabular}{lcccc}
\hline & Native women $(\mathbf{n}=\mathbf{1 0 0 0})$ & Migrant women $(\mathbf{n}=\mathbf{1 0 0 0 )}$ & RR (95\% CI) & p \\
\hline Weight $<2500 \mathrm{~g}^{*}$ & $99(9.9)$ & $53(5.3)$ & $0.53(0.3-0.7)$ & $<0.001$ \\
Weight $<1500 \mathrm{~g}^{*}$ & $14(1.4)$ & $14(1.4)$ & $1(0.47-2)$ & 0.57 \\
Gestational age $<37$ weeks* & $166(16.6)$ & $96(9.6)$ & $0.57(0.40-0.69)$ & $<0.01$ \\
Apgar score at 5 minutes $<5^{*}$ & $3(0.3)$ & $3(0.3)$ & $1(0.47-2)$ & 0.57 \\
Length of hospital stay\# & $3.4(2.5)$ & $3.5(3.5)$ & $1.02(0.58-2.1)$ & 0.46 \\
Phototherapy* & $143(14.3 \%)$ & $205(20.5 \%)$ & $1.43(1.2-2.4)$ & 0.04 \\
Respiratory distress* & $38(3.8)$ & $33(3.3)$ & $0.86(0.33-2.3)$ & 0.49 \\
Mortality (n) & 8 & 9 & $1.12(0.44-2.33)$ & 0.8 \\
\hline
\end{tabular}

*n (\%) \# Mean \pm SD

TABLE 3. Maternal results

\begin{tabular}{lcccc}
\hline & Native women $(\mathbf{n = 1 0 0 0 )}$ & Migrant women $(\mathbf{n = 1 0 0 0 )}$ & RR (95\% CI) & p \\
\hline Marital status & & & & \\
$\quad$ - Single & $468(46.8)$ & $386(38.6)$ & $0.82(0.45-2.5)$ & 0.03 \\
$\quad$ - Married & $96(9.6)$ & $106(10.6)$ & $1.1(0.48-2.44)$ & 0.5 \\
$\quad$ - Stable partner & $434(43.4)$ & $506(50.6)$ & $1.16(0.5-2.89)$ & $<0.01$ \\
Age $<$ 17 years old & $60(6)$ & $13(1.3)$ & $0.2(0.11-0.27)$ & $<0.01$ \\
Control $<5$ & $134(13.4)$ & $217(21.7)$ & $1.61(1.08-2.9)$ & $<0.01$ \\
Gestational hypertension & $67(6.7)$ & $41(4.1)$ & $0.6(0.2-1.3)$ & 0.15 \\
Positive serology for Chagas disease & $4(0.4)$ & $32(3.2)$ & $7.2(1.6-30)$ & $<0.01$ \\
\hline
\end{tabular}

$n(\%)$ 
and RDS; however, there were more low birth weight infants $(<2500 \mathrm{~g})$ in the Argentine women population; these results are not consistent with the conclusions of the reviewed bibliography. ${ }^{5-7}$ One of the causes described in the reviewed bibliography is that the rate of smoking native women is five times higher than, i.e., in the Bolivian population, ${ }^{13}$ which may have contributed to the low birth weight of infants born from Argentine women. The higher prevalence of adolescent pregnancies among this population may also be related to the low birth weight. The percentage of newborn infants with a gestational age $<37$ weeks accounted for $13.1 \%$ (and this data is consistent with the hospital's statistics $\left.{ }^{8}\right)$, with a higher rate among Argentine women versus migrant women, and this also explains the higher rate of low birth weight infants. ${ }^{13}$ This is relevant because it is an indicator of prenatal development, with short and long term consequences on the child and a direct relationship with neonatal mortality. ${ }^{14}$

A higher number of adolescent pregnancies was observed in Argentine women, which may also account for the lower gestational age and their infants' low birth weight, ${ }^{15,16}$ regardless of the number of antenatal controls they underwent. This is an important piece of information for the public health system and underscores the need to continue studying and acting upon the multiple factors associated with adolescent pregnancy both to understand why this population gets pregnant (individual, psychosocial and biological reasons have been described ${ }^{17}$ and the likely associated risks for the mother and the child. In the group of native women a higher rate of single mothers and with fewer stable relationships were found. This is also important information to be considered since it might be related to the emotional containment of these mothers and influence perinatal results.

Likewise, migrant women have fewer antenatal controls. Their resistance to seek care may be due to their fear of being reported in case of irregularities or fear of losing their jobs in case they have to take the day off to see a doctor, especially because visits usually take place during working hours. Cultural differences are also strongly related to having fewer antenatal controls because of the type of care proposed by modern medicine, as opposed to traditional care, which even leads to differences in how health and disease processes are perceived and experienced.

In addition, a higher percentage of migrant women tested positive for Chagas disease, which is probably related to their long stay in endemic areas. Their newborn infants also have a higher risk of hyperbilirubinemia that requires treatment, and this difference may also be explained by the racial factor.

No conclusions can be drawn regarding health and disease processes of migrant families without taking into consideration the sociocultural aspects of each population, because they have an intangible social capital for dealing with health issues based on their personal experience and family history. ${ }^{3}$

Our study has limitations like not knowing the time of residence of migrant women under study in Argentina, their understanding of perinatal health, whether they have containment networks (e.g., as in Bolivian communities), and the difficulties that they and health care providers have to go through in order to overcome communication, linguistic and cultural barriers. This last aspect has also been a reason for concern in other recipient countries. ${ }^{18-20}$

Another limitation of this study is that pregnancies not followed-up at the hospital were excluded because there were neither data registered on the medical records nor native population seen in other health care facilities that may have belonged to different social classes.

It is important to conduct studies on the links between health and migration that allow to anticipate possible challenges to public health resulting from migration, such as changes in risk behaviors, the dismantling of family social networks and, in some cases, the development of new local networks.

As health care providers, it would be interesting to develop a comprehensive vision of migrant populations, leaving aside prejudices deeply rooted in our society. Cultural fusion is a reality that calls for the development of the necessary space and understanding, within a solidarity framework, so as to jointly achieve a successful transition. ${ }^{21}$

\section{CONCLUSION}

Significant differences have been found in the perinatal risk of Argentine and migrant mothers and of their newborn babies assisted at the HMIRS: among Argentine women, there is a higher rate of adolescent pregnancies, single mothers, primiparity, low birth weight and less than 37 weeks of gestation. Among migrant women, there is a higher rate of positive serology for Chagas disease, scarce antenatal control visits 
and the need of phototherapy in newborn infants.

The study of accessibility to the health care system, social containment networks and protection processes are essential to be able to explain these differences.

\section{REFERENCES}

1. Organización internacional para las migraciones. A propósito de la migración. [Acceso: 1 set 2012] http:// www.iom.int/jahia/Jahia/about-migration/lang/es.

2. Everett, S. Lee, A theory of migration, en Robin Cohen, (ed.), Theories of migration, An Elgar Reference Collection, Cheltenham, UK, 1996.

3. Lauo C, Brykman D, Perez Paneli A, Rovere M, et al. Migraciones y salud en el area Metropolitana Buenos Aires. El Agora. 2006.

4. Cortés CastellanosP,Mujeres migrantes de América Latina y el Caribe: derechos humanos, mitos y duras realidades. Santiago de Chile: CEPAL 2005: 61.

5. Bollini P, Pampallona S, Wanner P, Kupelnick B, Pregnancy outcome of migrant women and integration policy: A systematic review of the international literature. Socscimed 2009;68:452-61.

6. Sosta E, Tomasoni LR, Frusca T, Triglia M, et al. Preterm delivery risk in migrants in italy: an observational prospective study. J Travel Med 2008;15(4): 243-247.

7. Río I, Castelló A, Jané M, Prats R, Barona C, Más R, et al. Indicadores de salud reproductiva y perinatal en mujeres inmigrantes y autóctonas residentes en Cataluña y en la Comunitat Valenciana. Gac Sanit 2010;24(2):123-127.

8. División Estadística, Sistema Informático Perinatal. Departamento Técnico. HMIRS Estadísticas Sardá 2010. Comparación con los años 2008-2009. Rev. Hosp. Mat. Inf. Ramón Sardá 2011;30(3):127-42.

9. Martínez JC, El real problema del recién nacido ictérico. Nuevas guías de la Academia Estadounidense de Pediatría. Arch Argent Pediatr 2005; 103(6): 524-32.
10. Jovanovic L, PettittDJ. Gestational Diabetes Mellitus. JAMA 2001;286 (20): 2516-18.

11. Reyes H. Rewiew: Intrahepatic Cholestasis. A puzzling disorder of pregnancy. J Gastroenterol Hepatol 1997; 12(3): 211-6.

12. Mora L. Globalización, migración internacional y división sexual del trabajo. Una mirada desde el género y los derechos reproductivos. CEPAL 2007; 85: 115-144.

13. Cerutti M. Salud y migración internacional: mujeres bolivianas en la Argentina. Buenos Aires: Latingráfica; 2010.

14. DeMucio B, Fescina R, Schwarez A, Garibaldo MC, Mendéz Valdemarín GC. Regionalización de la atención perinatal. CLAP/SMR-OPS/OMS. Mayo 2010, Buenos Aires, MSAL; 2001.

15. Díaz A, Sanhueza R, Yaksic B. Riesgos obstetricos en el embarazo adolescente: Estudio comparativo de resultados obstetricos y perinatales con pacientes embarazadas adultas. Rev chil obstet ginecol 2002; 67(6): 481-487.

16. Padilla deGil. Aspectos médicos y sociales dela maternidad en la adolescencia. Rev Sogia 2000; 7(1):16-25.

17. Pasqualini D, Llorens A. Salud y bienestar de adolescentes y jóvenes: Una mirada integral. $1^{\text {a }}$ ed. OPS/OMS. 2010.

18. Zuppa AA, Orchi C, Calabrece V,Verrillo G, Perrone S, Pasqualini $\mathrm{P}$, et al. Maternal and neonatal characteristics of an immigrant population in an Italian hospital. J Matern Fetal Neonatal Med 2010; 23(7): 627-32.

19. Small R, Gagnon A, Gissler M, Zeitlin J, Bennis M, Glazier R, et al. Women and their pregnancy outcomes postmigration: data from six receiving countries. BJOG 2008;115(13):163040.

20. Río Sánchez I, Bosch Sánchez S, Castelló Pastor A, LópezMaside A, García Senchermes C, Zurriaga Llorens O, et al. Evaluación de la mortalidad perinatal en mujeres autóctonas e inmigrantes: influencia de la exhaustividad y la calidad de los registros. Gac Sanit 2009; 23(5): 403-09.

21. Aisenstein C, Inmigración y salud mental materno-infantil. Perinatal Reprod Human 2001;15:42-51. 